\title{
Developing Weighted Phonological Mean Length of Utterance and Testing the Validity
}

\author{
Minjung Kim ${ }^{\mathrm{a}}$, Seunghee $\mathrm{Ha}^{\mathrm{b}}$ \\ ${ }^{a}$ Dogok Yonsei Speech-Language Clinic, Seoul, Korea \\ ${ }^{b}$ Division of Speech Pathology and Audiology, Audiology and Speech Pathology Research Institute, Hallym University, Chuncheon, Korea
}

\author{
Correspondence: Seunghee $\mathrm{Ha}, \mathrm{PhD}$ \\ Division of Speech Pathology and Audiology, \\ Audiology and Speech Pathology Research \\ Institute, Hallym University, 1 Hallymdaehak-gil, \\ Chuncheon 24252, Korea \\ Tel: $+82-33-248-2215$ \\ Fax: +82-33-256-3420 \\ E-mail: shha@hallym.ac.kr
}

Received: July 20, 2018

Revised: August 10, 2018

Accepted: August 29, 2018

This study was supported by Hallym University Research Fund (HRF-201807-008).
Objectives: It is important to develop a speech measure which accurately and sensitively reflects speech production skills, and to test the validity of such a measure. This study aims to examine the validity of a new speech measure, weighted phonological mean length of utterance (PMLU-W) by comparing percent consonants correct (PCC) and phonological mean length of utterance (PMLU) from speech analyses of typically developing children and children with speech sound disorders (SSD). Methods: The PCC, PMLU, and PMLU-W of 220 typically developing children and 18 children with SSD aged from 2;6 to 6;6 were derived from the Assessment of Phonology and Articulation for Children. PMLU-W was evaluated to examine whether it correlates with PCC and PMLU, and to see if it is sensitive to changes in speech development over time. Also, this study evaluated whether PMLU-W reflects phonological error patterns in children with SSD shows severe, moderate, or mild severity differently. Results: The results showed that PMLU-W strongly correlates with PCC and PMLU, and sensitively captures normal speech development over time. PMLU-W better reflects the characteristics and nature of speech problems in children with SSD compared to the existing measures. In particular, PMLU-W is useful in distinguishing children with SSD who show syllable or phoneme deletions, vowel errors or atypical consonant substitutions. Conclusion: This study found that PMLU-W would be a valid and sensitive measure of normal and disordered speech in children and be useful to quantify the characteristics and types of speech error patterns.

Keywords: Percent consonants correct, Phonological mean length of utterance, Weighted phonological mean length of utterance, Typically developing children, Speech sound disorder
조음음운장애를 평가할 때 말소리 산출상의 문제 여부를 판단 하고 심각도 및 특성을 파악하기 위해서는 말소리 산출 능력을 정 확하고 민감하게 반영할 수 있는 객관적 지표를 선택하여 사용하 는 것이 중요하다. 현재 임상이나 연구현장에서 일반아동의 조음 음운발달 정도를 파악하거나 말소리장애의 유무를 진단할 때 가 장 보편적으로 사용되는 지표는 자음정확도이다(Shriberg \& Kwiatkowski, 1982). 자음정확도는 목표 자음 산출을 정-오반응의 이 분법적인 체계로 나누어 정조음된 자음의 수를 백분율로 나타낸 값으로, 계산이 간단하고 아동의 조음음운 능력을 정량화하여 해 석하는 것이 용이해 대부분의 국내외 표준화 검사도구에서 이를
규준치로 제시하고 있다. 하지만 자음 산출의 정확성을 이분법적 으로 살펴보기 때문에 조음오류의 유형과 특성을 반영하지는 못한 다(Preston, Ramsdell, Oller, Edwards, \& Tobin, 2011). 예를 들어 목표단어 '차'를 [타], [하], [아]로 각각 발음하는 세 명의 평가 대상 자가 있다고 가정하면, 이들은 모두 동일한 자음정확도를 보이지만 생략과 대치([아] vs. [타], [하]), 발달적 오류와 비발달적/특이한 오 류([타] vs. [하], [아])를 보여 조음오류의 유형과 특성 및 심각도 면 에서는 서로 다르다.

이에 자음정확도의 제한점을 보완할 수 있는 측정치를 고안하고 그 임상적 타당도와 효율성을 살펴보고자 하는 시도가 이어졌다. 
Shriberg, Austin, Lewis, McSweeny와 Wilson (1997)은 모음 오류 까지 고려한 음운정확도, 자음의 왜곡오류를 정반응의 범위에 포 함시킨 개정자음정확도, 자음의 왜곡오류 중 발달적일 것만 정반 응의 범위에 포함시킨 조정자음정확도 등을 제안하였다. 연구자들 은 음운정확도는 모음에도 오류를 보이는 말소리장애 사례의 평가 에 필요한 지표이며, 기존의 자음정확도는 일반아동의 발달을 나 타내는 데 유용하지만, 말소리장애 아동의 평가에는 개정자음정확 도나 조정자음정확도가 더 유용하다고 언급하였다.

Preston 등(2011)은 자음정확도를 계산할 때 0 또는 1점의 이원 화된 점수 체계가 아닌 말소리 오류에 따라 가중치를 적용하는 방 법을 제안하였다. 이 연구에서 제안한 측정치는 가중 말소리 정확 도(weighted measure of speech sound accuracy, WSSA)로 일반적 인 대치오류와 구별하여 음소의 생략과 조음방법, 조음위치, 발성 유형면에서 특이한 대치오류에 가중치를 적용하여 계산하였다. 즉 분절음이 갖고 있는 자질을 정확하게 산출한 정도에 따라 차등적 으로 점수를 매겨 심각도 면에서 주요하거나 발달적으로 특이한 오 류는 0에 가까운 낮은 점수로 계산하였다. 선행연구는 WSSA가 기 존의 자음정확도뿐만 아니라 심각도에 대한 임상가의 청지각적 판 단과 높은 상관관계가 있으며, 정확도의 발달적 변화와 말소리장애 의 유무를 잘 나타내줄수 있다고 제시하였다.

2000년대에 들어서서 Ingram은 대부분의 측정치가 분절음 특 히 자음에만 초점을 맞추고 있음을 지적하면서 평균음운길이라는 단어의 음절구조와 복잡도를 반영한 측정치를 제안하였다(Ingram \& Ingram, 2001; Ingram, 2002). 평균음운길이는 자음과 모음이 산출되었으면 1점을 부여한 뒤에 정확한 자음에 1 점을 추가적으로 부여하는 점수 체계로, 아동이 산출한 단어의 자음정확도뿐만 아 니라 음절구조의 복잡도를 반영할 수 있는 지표이다. 따라서 평균 음운길이는 주로 1-2어 조합으로 의사소통을 하면서 음소 수준이 아닌 통단어 수준에서 말소리를 산출하고 다음절어의 음절 생략 및 축약을 보이는 음운발달 초기 단계에 있는 아동의 말소리 평가 에 유용하다. 국내에서도 여러 연구자들이 다양한 연령대의 일반 아동과 말소리장애 아동을 대상으로 평균음운길이를 활발히 연 구하였다(Ha \& Hwang, 2013; Ha, Seol, So, \& Pae, 2016; Seok, 2004; Shin \& Lee, 2015; Yoon, Kim, \& Kim, 2013). Kim (2012)은 표현언 어지체 아동의 말소리발달을 나타내는 데 평균음운길이가 효과적 으로 사용될 수 있음을 보여주었다. 그 자료에 따르면 표현언어지체 아동은 ‘덮어'의 산출을 [어], [퍼], [어퍼], [버퍼], [더퍼] 순서로 발달 시켜 나갔는데 이러한 조음음운발달은 음운길이를 통해 민감하게 파악될 수 있었다. 즉 자음정확도는 [퍼], [어퍼], [버퍼]에서 모두 $50 \%$ 로 동일하지만, 음운길이는 $3,4,5$ 로 증가하기 때문이다. 이러
한 자료는 기존의 자음정확도가 조음음운발달 초기에 일반아동 이 음절구조의 발달을 보일 때나 말소리장애 아동이 치료에 대한 반응으로 음절구조의 향상을 보일 때 그 변화를 민감하게 반영하 지 못하는 제한점을 시사한다. Ingram과 Ingram (2001)도 말소리 장애 아동의 말 샘플 분석과 단어 음절구조의 복잡도 및 음소의 정 확도 증진을 위한 치료 목표 기술에 평균음운길이가 어떻게 사용 될 수 있는지 그 예를 구체적으로 제시함으로써 평균음운길이의 임상적 유용성을 보여주었다.

평균음운길이가 아동이 산출하는 단어의 길이 및 음절구조의 복잡성, 자음 산출의 정확성을 동시에 반영하는 장점이 있지만 평 균음운길이에도 제한점이 있다. 먼저 평균음운길이는 모음의 경우 산출 여부만 반영하고 오류 유무는 반영하지 않는다. 1 세 아동은 고모음화, 전설모음화, 평순모음화, 원순모음화와 같은 모음오류가 관찰된다고 하였다(Ahn, Kim, \& Kim 2004). 이러한 모음오류는 일반아동에게는 출현빈도가 낮지만, 말소리장애, 표현언어지체, 말 실행증 아동에게는 자주 관찰되므로 말소리장애 진단에서 간과해 서는 안 되는 증상이다(Davis, Jakielski, \& Marquardt, 1998; Dodd \& Bradford, 2000; Pollock, 1991). 평균음운길이의 또 다른 한계는 자음 점수를 줄 때, 정조음 또는 생략 및 대치오류 여부만 반영하고 대치가 목표음과 얼마나 유사한지는 반영하지 않는다. 자음오류의 대치 양상, 즉 음운패턴은 말소리장애의 진단 및 유형 분류에 주요 한 기준이다(Bernthal, Bankson, Flipsen, 2013). 예를 들어 일반아 동이 [지 계열을 같은 설정성 장애음인 [ㄷ] 계열로 대치하는 발달 적 음운패턴을 보였다면 조음위치는 유지하고 조음방법만 대치한 것이다. 그러나 말소리장애 아동이 [ㅈ] 계열을 [ㄱ] 계열로 대치하 는 비발달적인 음운패턴을 보였다면 조음위치와 조음방법을 모두 대치한 것이다(Kim \& Lee, 2010; Lowe, 1994). 아동의 말소리 습득 과정이 말소리의 여러 자질을 점진적으로 충실하게 산출해가는 과 정이라면 그러한 과정을 면밀하게 정량화하여 살펴볼 수 있는 지표 라야음운발달 파악 및 말소리장애 진단에 유용할 것이다.

말소리장애의 특성을 더 잘 이해하고 정확하게 평가하기 위해서 는 말소리 산출 능력을 타당하고, 민감하게 반영할 수 있는 객관적 지표에 대한 지속적인 고민과 개발이 필요하다(Preston et al., 2011). 본 연구는 기존 임상과 연구현장에서 보편적으로 사용되고 있는 자음정확도와 평균음운길이의 임상적 효용성과 제한점을 고려하 여 일반아동의 점진적인 말소리 습득 과정을 보다 민감하게 반영하 고 말소리장애 아동의 오류패턴의 특징과 심각도를 정량화할 수 있는 객관적 지표를 새롭게 개발하고 타당도를 검증하고자 하였다. 단순히 분절음의 정-오반응을 정량화하는 한계를 넘어서서, 아동 이 목표 낱말의 음절구조와 모음의 정확도를 충실하게 지켜나가면 
서 자음의 자질을 점진적으로 정확하게 산출해 나가는 발달 과정 을 세밀하게 반영하는 측정치를 개발하고자 하였다. 이러한 개발 목적과 점수체계를 가진 측정치를 가중평균음운길이라고 명명하 고, 일반아동과 말소리장애 아동의 말 자료를 토대로 계산하여 자 음정확도 및 평균음운길이와 비교하면서 새롭게 개발 제안하는 지 표의 타당도를 살펴보고자 한다.

본 연구는 세부적인 연구목적에 따라 두 가지 소연구로 구성하 였다. 첫 번째는 만 2세 후반부터 6세 전반의 일반아동을 대상으로 단어검사 반응에서의 가중평균음운길이 구하여 자음정확도 및 평균음운길이와 비교하면서 새로운 수치가 아동의 조음음운발달 을 민감하게 나타내는지 살펴보고자 하였다. 두 번째는 말소리장 애 아동을 자음정확도를 토대로 심각도별 하위 유형을 나눈 후 자 음정확도는 동일하지만 주요 오류패턴이 상이한 말소리장애 아동 끼리 평균음운길이 및 가중평균음운길이를 살펴봄으로써 가중평 균음운길이가 기존의 측정치보다 아동의 조음음운 문제의 양상과 본질을 보다 민감하게 나타내는지 살펴보고자 하였다.

\section{연구방법}

\section{대상자}

연구 1: 세가지 측정치를 통한 일반아동의 조음음운발달 패턴

첫 번째 연구에서는 아동용발음평가(Assessment of Phonology and Articulation for Children, APAC; Kim, Pae, \& Park, 2007)의 표준화에 사용된 일반아동 220 명을 대상으로 하였다. 이들은 세 곳의 유치원에 재원 중인 2 세 6 개월부터 6 세 5 개월의 일반 아동으 로, 6개월 단위로 20-30명씩 분포해 있었고(2세 후반과 3세 전반은 20 명씩, 나머지 연령대는 30 명씩), 남아와 여아의 비율은 동일하였 다. 이들은 모두 (1) 한쪽 귀의 순음청력검사에서 $20 \mathrm{~dB}$ 의 $500 \mathrm{~Hz}$, $1 \mathrm{kHz}, 2 \mathrm{kHz}, 4 \mathrm{kHz}$ 소리에 반응을 보였으며, (2) 운동구어장애나 구개열 병력이 없었고, (3) 그림어휘력검사(Kim, Jang, Yim, \& Baek, 1995)에서 백분위수가 10 이상이었다.

\section{연구 2: 말소리장애 아동을 대상으로 세가지 측정치 비교}

두 번째 연구에서는 2 세 8 개월부터 5 세 9 개월의 말소리장애 아 동 18 명(남 12 명, 여 6 명)을 대상으로 하였다. 이들은 3년간 소아과 소속 발달연구소의 언어치료실에 발음부정확을 이유로 내원한 아 동 중에서 선별하였다. 기질적 원인이 있거나 발달장애나 지적장애 로 진단받은 아동은 제외하였고, 언어발달지체가 있거나 말소리장 애가 있는 아동 중에서 자음정확도는 동일하지만 오류패턴이 서로 다른 아동들을 포함하였다.

\section{자료 수집 및 분석}

말소리장애 임상경력이 5 년 이상인 제 1 연구자가 조용한 빈 방에 서 대상자와 일대일로 $\mathrm{APAC}$ 단어검사를 직접 실시하였고, 검사 과 정은 디지털 캠코더(Panasonic NV-MX2500, Japan)에 디지털 마 이크(Sony ECM-/MS908C, Japan)를 연결하여 녹화하고 녹음하였 다. 아동에게 그림을 보여주고 자발적으로 이름을 말하도록 하였 고, 명료도가 현저히 떨어질 때에는 명료화를 요구하여 2차 반응 을 유도하였으며, 아동이 이름을 모르는 경우에는 '이거는 0 양. 이게 뭐라고?’라고 질문하여 자연스럽게 반응을 유도하였다.

연구자는 녹음 또는 녹화된 자료를 보고 37 개 단어의 반응을 전 사하고 단어에 포함된 77 개 모음과 96 개 자음의 반응을 음소별로 모두 확인하였다. 각 단어마다 첫 번째 명료한 반응으로 분석하였 고, 아동이 발음을 자가수정을 한 경우에는 최종 반응으로 분석하 였다. 음소별로 정조음은 '+', 생략은 '생', 대치는 대치된 음소, 왜곡 은 ‘왜'로 표기하였다. 아동의 음소 반응 분석 시 혼돈이 될만한 사 항은 다음과 같이 정하였다. ‘호랑이'를 [호야니]로 산출했다면 [리 을 [j]로 대치하고 [0]을 [ㄴ] 로 대치한 것으로 분석하였다. '장갑'을 [자깝]로 산출했다면 [이을 [ㄱ]으로 대치한 현상으로도 해석할 수 있으나, 그 해석을 입증하려면 다양한 요인을 고려해야 하므로, [ㅇ] 을 생략하고 [ᄀᄀ]를 [ᄁ]]로 대치한 현상으로 분석하였다. ‘옥수수’를 [오쑤수]로 산출한 경우에도 / ᄀ /를 [ᄃ]로 대치한 것으로 해석할 수 있지만, 이 해석을 입증하려면 다양한 요인을 고려해야 하므로, [ㄱ] 생략으로 분석하였다. 또한 구개음화 왜곡(예: '시소' $\rightarrow[\operatorname{sico}])$ 을 활음 첨가로 분석하거나, 유음의 설측음화 왜곡을(예: ‘고래' $\rightarrow[\mathrm{kole}]$ ) 유음 첨가로 분석하지 않도록 주의하였다.

\section{자음정확도, 평균음운길이, 가중평균음운길이의 계산 및 음운패턴의 분석}

자음정확도(percentage of consonants correct, PCC)는 APAC의 96 개 자음 중에서 ' + '인 자음의 비율을 계산하였다. 평균음운길이 (phonological mean length of utterances, PMLU)는 각 단어마다 음운의 길이를 계산하여 단어수인 37로 나누어 평균을 구하였다. 음운의 길이는 Ingram (2002)이 제시한 대로, 산출된 모음과 자음 마다 1점을 부여하고, ‘’’된 자음마다 1점의 추가점수를 부여하여 계산하였다. Ingram (2002)이 특별히 언급하지 않은 사항에 대해서 는 아래와 같이 점수를 부여하였다. 이중모음에 대해서는 모음과 동일하게 정조음 여부와 관계없이 산출되면 점수를 부여하였으며, 단모음으로 산출되면 1점, 이중모음으로 산출되면 2점을 부여하였 다. 성문파열음으로의 대치에 대해서는 성문파열음이 구강기제의 움직임으로 인한 구강 내 막힘을 동반하면서 소리가 만들어지는 진 
자음(true consonants)이 아니기 때문에(Chapman, Hardin-Jones, \& Halter, 2003) 생략과 동일하게 점수를 부여하지 않았다. 왜곡에 대해서는 길이 점수만 부여하고 정조음 점수는 부여하지 않았다.

본 연구에서 개발한 가중평균음운길이(weighted phonological mean length of utterances, PMLU-W)는 PMLU와 마찬가지로 산 출된 모음과 자음마다 1 점을 부여하였으나, 추가점수 체계는 세분 화하였다. 모음의 정확성 여부를 고려하지 않는 PMLU와는 다르게 PLMU-W는 모음도 정확하게 산출되면 1점의 추가점수를 부여하였 고, 자음은 정확하게 산출되면 2점의 추가점수를 부여하였다(단, [ㅎ]의 정조음에 대해서는 [ᄒ]가 진 자음이 아니기 때문에 1 점의 추가점수만 부여하였다). 자음에 대치 및 왜곡오류가 있을 때에는 오류패턴에 따라서 부분적인 추가점수를 주었다. 본 연구에서 개 발한 PMLU-W는 Pi \& Ha (2018)에서 평균자질길이(Feature mean length of utterance)로 명명되었던 측정치와 동일하며, 일부 세부점 수체계를 본 연구에서 수정보완하였다.

대치와관련한추가점수체계는 음운발달을 참고하여 정하였다. 일 찍 발달하는 파열음과 비음은 우리말에서 조음위치와 발성유형면에 서 다양한말소리로, 파열음과 비음 ‘내’에서의 조음위치, 조음방법, 발 성유형 오류는 연령이 낮은 아동에게 흔한 현상이다. 예를 들어, 연구 개음의 전방화나 어중 단순화와 같은 조음위치 변화, 긴장음화나 기 식음화와같은 발성유형 변화는 일반아동에게자주 관찰되는 음운패 턴이며, 특정 문맥에서의 연구개음화나탈비음화도 일반아동에게 종 종 관찰되는 음운패턴이다(Kim, 2015; Kim \& Lee, 2010; Kim et al., 2007; Woo \& Kim, 2013). 그러나 일찍 발달하는 파열음과 비음이 늦게 발달하는 파찰음, 마찰음, 유음으로 대치되는 현상은 일반아동에게 거의 나타나지 않는다. 이에 일찍 습득되고 다양한 조음위치 그리고/ 또는 발성유형이 있는 파열음과 비음에 대해서는 파열음과 비음 '내' 에서조음위치가 동일하거나조음방법-발성유형이 동일하면 1점의추 가점수를 주었다. 예를 들어 파열음인 [ㄷ] 은 동일한 조음위치인 [ᄄ, $\mathrm{E}, \mathrm{L}]$ 으로의 대치이거나 동일한 조음방법-발성유형인 [빅]으로의 대치라면 1 점의 추가점수를 주지만, 조음위치와 발성유형이 모두 다 른 [ㅋ]로의 대치이거나 늦게 발달하는 [ᄌ, ㅅ,리 계열로의 대치라면 추가점수를 주지 않았다. 비음인 [이은 동일한 조음위치인 [ᄀ, ㄱ, ㅋ] 으로의 대치이거나 동일한 조음방법인 [ㅁㄴ]으로의 대치라면 1점의 추가점수를 주지만 조음위치와 조음방법이 모두 다른 [ㅂ] 으로의 대 치이거나 늦게 발달하는 [ᄌ, ㅅ,리 계열로의 대치라면 추가점수를 주 지 않았다.

늦게 발달하는 파찰음, 치경마찰음, 유음은 모두 설정성의 조음 위치에서만 산출되고, 이 말소리에 대한 발달적 대치 음운패턴은 동 일한 조음위치에서 일찍 습득되는 조음방법으로 변하는 것이다. 구
체적으로 파찰음은 치경파열음으로, 마찰음은 치경파열음이나 파 찰음으로, 유음은 활음이나 치경 비음 및 파열음으로 대치된다 (Kim, 2015; Kim et al., 2007). 이에 늦게 습득되고 하나의 조음위치 로 산출되는 파찰음과 마찰음과 유음에 대해서는 위에 언급한 발 달적 음운패턴에 1 점의 추가점수를 주었다. 구체적으로 파찰음은 [ᄃ] 계열로의 대치거나 발성유형만 다른 파찰음으로의 대치라면 1 점의 추가점수를 주지만, 비음이나 마찰음이나 유음으로의 변화는 추가점수를 주지 않았다. 치경마찰음도 마찬가지로 발달적 대치 음 운패턴에 해당하는 [ᄃ, 지 계열로의 대치이거나 발성유형만 다른 마찰음으로의 대치라면 1점의 추가점수를 주지만, 비음이나 유음 으로의 변화는 추가점수를 주지 않았다. 유음은 [ᄂ,ㄷ] 및 활음으 로의 대치라면 1점의 추가점수를 주지만, 마찰음이나 파열음으로 의 변화는 추가점수를 주지 않았다. 또한 다른 조음위치인 양순음 이나 연구개음으로의 변화도 추가점수를 주지 않았다. 마지막으로 모든 왜곡에 대해서도 1점의 추가점수를 주었다. 각 음소별 점수는 엑셀 수식을 이용하여 자동적으로 계산되도록 하였다.

말소리장애 아동의 경우에는 구체적인 오류패턴에 대한 분석도 진행되었다. 두 연구자가 말소리장애 아동의 자료를 토대로 오류패 턴을 독립적으로 분석한 후 결과가 불일치했던 부분에 대한 논의 를 통해 일치된 결과로 정리하였으며 이 과정에서 오류패턴의 유형 과 정의를 세분화시켰다. 본 연구에서 사용한 오류패턴의 유형과 정의는 Appendix 1에 제시되어 있다.

\section{신뢰도}

전사의 신뢰도 분석에는 언어병리학과 석사를 졸업하고 일반아 동 및 말소리장애 아동의 말 자료를 연구자와 함께 들으면서 6 개월 간 듣기 및 전사 훈련을 한 임상경험 1 년 이상의 언어치료사 1 명이 참여하였다. 일반아동 중 가장 다양한 정확도가 분포해 있었던 3 세 아동 50 명과 다양한 심각도의 말소리장애 아동 12 명의 녹화 파일 을 보고 연구자의 전사가 정확한지를 판단하였다. 일반아동 및 말 소리장애 아동 자료에 대한 낱말 전사 일치도는 78.33\%-100\%였고, 자음의 전사 일치도는 $90.53 \%-100 \%$ 였다.

\section{통계 분석}

통계 처리는 SPSS 22.0 프로그램을 사용하였다. 첫 번째 소연구 를 위해서는 먼저 PCC, PMLU, PMLU-W의 상관분석을 실시하였 다. 이후 세가지 측정치가 연령집단 간 차이를 나타내는지 살펴보기 위해 각 측정치별로 일원분산분석을 실시하였으며. 사후분석으로 Scheffe 검정을 실시하였고 모든 유의수준은 $p<.05$ 로 설정하였다. 


\section{연구결과}

\section{연구 1: 세가지 측정치를 통한 일반아동의 조음음운발달 패턴}

연령집단별 일반아동의 PCC, PMLU, PMLU-W에 대한 결과는 Table 1 에 제시하였다. APAC 의 37 개 검사어를 모두 정조음한 경우 PMLU는 7.3, PMLU-W는 12.1이다. 세가지 측정치 모두 연령이 증 가함에 따라 꾸준히 증가하여 대다수의 6세 전반 아동은 성인의 목 표 발음 형태에 도달하는 것으로 나타났다. 일반아동의 APAC 말 자료를 토대로 계산한 PMLU-W와 다른 두 측정치의 피어슨 상관 계수를 살펴보았는데 PMLU-W는 PCC와 $r=.971, \mathrm{PMLU}$ 와 $r=.985$ 의 높은 상관관계를 보였다 $(p<.001)$.

또한 연령집단에 따라 세 측정치가 유의미하게 다른지를 살펴보 기 위해 일원분산 분석을 실시한 결과 $\operatorname{PCC}\left(F_{(7,212)}=38.587, p<.001\right.$, $\left.\eta_{\mathrm{p}}^{2}=.560\right), \mathrm{PMLU}\left(F_{(7,212)}=39.508, p<.001, \eta_{\mathrm{p}}^{2}=.566\right)$, PMLU-W $\left(F_{(7,212)}=43.865, p<.001, \eta_{\mathrm{p}}{ }^{2}=.592\right)$ 모두 유의미한 차이를 보였다. 사후분석으로 Scheffe 검정을 실시한 결과, PCC는 2세 후반이 모 든 연령 집단과 유의미한 차이를 보였으며, 그 외에 3 세 전반이 4 세 전반 이상의 연령 집단, 3 세 후반이 5 세 전반 이상의 연령 집단과 유 의미한 차이를 보였다 $(p<.05)$. PMLU와 PMLU-W에 대한 사후분 석은 서로 결과가 동일하였으며 PCC 사후분석 결과와도 대부분 일치하였으나, 3 세 후반이 5 세 전반과는 유의미한 차이를 보이지 않 고, 5 세 후반 이상의 연령 집단과 유의미한 차이를 보였다 $(p<.05)$. 세가지 모든 측정치에 대한 사후분석 결과를 종합해 보면 세가지 측정치가 2 세 후반부터 3 세 후반까지 큰 폭으로 유의미하게 증가하 다 이후에는 조금씩 꾸준히 발달하다가 5 세 이후에는 안정기에 도 달하였다.

Table 1. Descriptive statistics for PCC, PMLU, and PMLU-W

\begin{tabular}{lccccccccc}
\hline & Highest & \multicolumn{7}{c}{ Age group (yr;mo) } \\
\cline { 3 - 9 } & score & $2 ; 6-2 ; 11$ & $3 ; 0-3 ; 5$ & $3 ; 5-3 ; 11$ & $4 ; 0-4 ; 5$ & $4 ; 6-4 ; 11$ & $5 ; 0-5 ; 5$ & $5 ; 6-5 ; 11$ & $6 ; 0-6 ; 5$ \\
\hline Number of subjects & & 20 & 20 & 30 & 30 & 30 & 30 & 30 & 30 \\
PCC & 100 & $66.40(12.47)$ & $79.59(10.09)$ & $85.36(8.25)$ & $88.96(7.78)$ & $92.09(7.60)$ & $92.89(5.96)$ & $95.14(3.79)$ & $95.87(4.08)$ \\
PMLU & 7.3 & $6.20(.44)$ & $6.67(.34)$ & $6.85(.25)$ & $6.94(.26)$ & $7.05(.20)$ & $7.08(.18)$ & $7.14(.10)$ & $7.16(.11)$ \\
PMLU-W & 12.1 & $10.51(.67)$ & $11.24(.49)$ & $11.50(.39)$ & $11.64(.35)$ & $11.79(.24)$ & $11.83(.18)$ & $11.91(.11)$ & $11.93(.12)$ \\
\hline
\end{tabular}

Values are presented as mean (SD).

$\mathrm{PCC}=$ percent consonants correct; $\mathrm{PMLU}=$ phonological mean length of utterance; PMLU-W= weighted phonological mean length of utterance.

Table 2. Three measurements and phonological error patterns of children who presented $10 \%-30 \%$ of PCC

\begin{tabular}{|c|c|c|c|c|c|c|}
\hline Case no. & $\begin{array}{c}\text { Age } \\
(y r ; m o)\end{array}$ & Gender & $\begin{array}{c}\text { PCC } \\
(100 \%)^{a}\end{array}$ & $\begin{array}{l}\text { PMLU } \\
(7.3)^{\mathrm{a}}\end{array}$ & $\begin{array}{l}\text { PMLU-W } \\
(12.1)^{\mathrm{a}}\end{array}$ & Main phonological error patterns ${ }^{b}$ \\
\hline 1 & $3 ; 4$ & M & 12.5 & 3.2 & 5.6 & $\begin{array}{l}\text { Glottalization (36.1), final consonant deletion (18.6), initial consonant deletion (6.2), frication (6.2), pala- } \\
\text { talization (6.2), typical simplification of consonant clusters between syllables (6.2) monophthongization } \\
\text { (5.2), substitution of vowels (5.2) }\end{array}$ \\
\hline 2 & $2 ; 8$ & M & 12.5 & 4.1 & 6.6 & $\begin{array}{l}\text { Tensing (21.0), final consonant deletion (16.0), backing to velars (13.6), initial consonants deletion } \\
\text { (12.8), Substitution of vowels (12.0), deaspiration (8.0), monophthongization (5.6), denazalization (3.2), } \\
\text { fronting of velars (2.4) }\end{array}$ \\
\hline 3 & $2 ; 10$ & M & 19.8 & 2.6 & 4.2 & $\begin{array}{l}\text { Initial consonant deletion (31.4), syllable deletion (29.7), final consonant deletion (17.8), glottalization } \\
\text { (5.1), fronting of velars (5.1), substitution of vowels (5.1) }\end{array}$ \\
\hline 4 & $3 ; 4$ & $\mathrm{~F}$ & 19.8 & 3.8 & 6.5 & $\begin{array}{l}\text { Final consonant deletion (27.2), initial consonant deletion (26.1), substitution of vowels (9.8), stop- } \\
\text { ping(7.6), fronting of velars (7.6), monophthongization (6.5), syllable deletion (4.8), typical simplification of } \\
\text { consonant clusters between syllables (3.3) }\end{array}$ \\
\hline 5 & $2 ; 10$ & M & 19.8 & 4.2 & 6.8 & $\begin{array}{l}\text { Substitution of vowels (18.3), final consonants deletion (15.4), gliding (10.6), alveolarization (6.7), liquid } \\
\text { simplification (5.8), syllable deletion (4.8), monophthongization (3.8), stopping (3.8), palatalization (3.8), as- } \\
\text { piration (3.8), initial consonants deletion (2.9), fronting of velars (2.9) }\end{array}$ \\
\hline 6 & $5 ; 1$ & $\mathrm{~F}$ & 29.2 & 4.5 & 8.0 & $\begin{array}{l}\text { Final consonants deletion (32.9), stopping (21.1), initial consonants (13.2), fronting of velars (9.2), tens- } \\
\text { ing (7.9), monophthongization (6.6) }\end{array}$ \\
\hline 7 & $5 ; 7$ & M & 29.2 & 5.3 & 9.7 & $\begin{array}{l}\text { Labiodentalization (25.4), fronting of velars (21.1), affrication (12.7), stopping (7.0), liquid simplification } \\
\text { (7.0), dentalization (7.0), typical simplification of consonant clusters between syllables (5.6) }\end{array}$ \\
\hline
\end{tabular}

$\mathrm{PCC}=$ percent consonants correct; $\mathrm{PMLU}=$ phonological mean length of utterance; $\mathrm{PMLU}-\mathrm{W}=$ weighted phonological mean length of utterance.

avalues in parenthesis indicate the possible highest score of each measure.

bValues in parenthesis indicate the percentage of each error pattern out of the child's entire error patterns.

Bold error patterns indicate those occurring within $50 \%$ of upper cumulative ratio. 


\section{연구 2: 말소리장애 아동을 대상으로 세가지 측정치 비교}

두 번째 연구에서는 PMLU-W가 PCC와 PMLU와 비교해서 말 소리장애 아동의 오류패턴과 특성을 차별적으로 나타내는지 분석 함으로써 PMLU-W의 유용성을 살펴보고자 하였다. 심각도 별로 $\mathrm{PCC}$ 가 $10 \%-30 \%, 50 \%-60 \%, 70 \%-80 \%$ 인 말소리장애 아동으로 나 누어 동일한 PCC 수치를 보이는 말소리장애 아동끼리 PMLU 및 PMLU-W와 함께 주요 오류패턴을 비교해서 살펴보았다.

본 연구에 포함된 18 명의 말소리장애 아동의 생활연령 및 성별, 말소리 산출 특성은 Tables 2-4에 정리하였다. 말소리장애 아동 중 아동 $1,2,3$ 은 주로 단어로, 나머지 아동은 문장으로 의사소통을 하였다. 주요 오류패턴의 경우 $\mathrm{APAC}$ 검사에서 아동이 3회 이상으 로 보인 오류패턴을 고빈도 순서로 기재하였으며, 아동이 보인 전 체 오류에서 각 오류패턴이 차지하는 비율도 함께 기재하였다. Tables 2-4에서 아동이 보인 오류패턴 중 상위누적 비율이 50\%가 되 는 패턴은 진하게 표시하였다.
먼저 Table 2에는 PCC가 $10 \%-30 \%$ 인 말소리장애 아동들의 결과 를 제시하였다. 아동 1 과 2 는 PCC가 $12.5 \%$ 로 서로 동일하나 PMLU 와 PMLU-W는 대략 1점 정도의 차이가 났다. 두 아동의 조음특성 을 살펴보면 아동 1 은 대다수의 자음을 생략하거나 성문파열음으 로 대치하여 제한된 음소목록을 보였다. 반면에 아동 2는 초성 및 종성 생략뿐만 아니라 긴장음화와 연구개음화와 같은 다른 자음으 로의 대치도 빈번하였다. 따라서 아동 1 과 2의 PCC는 동일하지만, 자음을 성문파열음으로 대치하는 아동 1 은 구강기제의 조음 움직 임을 동반한 진 자음으로 대치하는 아동 2 보다 PMLU와 PMLU$\mathrm{W}$ 가 더 낮았다.

아동 $3,4,5$ 도 PCC가 $19.8 \%$ 로 동일하였으나, PMLU와 PMLU$\mathrm{W}$ 의 수치는 서로 달랐다. 세 아동의 조음특성을 살펴보면, 아동 3 은 단어에 포함된 음절 중 한음절만 산출하여, 다른 아동에게는 거 의 관찰되지 않은 음절생략이 매우 빈번하였고, 이로 인해 음운길 이가 현저하게 낮아져서 다른 두 아동에 비해 PMLU는 1점 이상,

Table 3. Three measurements and phonological error patterns of children who presented $50 \%-60 \%$ of PCC

\begin{tabular}{|c|c|c|c|c|c|c|}
\hline Case no. & $\begin{array}{c}\text { Age } \\
\text { (yr;mo) }\end{array}$ & Gender & $\begin{array}{c}\text { PCC } \\
(100 \%)^{a}\end{array}$ & $\begin{array}{l}\text { PMLU } \\
(7.3)^{\mathrm{a}}\end{array}$ & $\begin{array}{l}\text { PMLU-W } \\
(12.1)^{\mathrm{a}}\end{array}$ & Main phonological error patterns ${ }^{b}$ \\
\hline 8 & $4 ; 8$ & M & 50.0 & 5.1 & 8.7 & $\begin{array}{l}\text { Final consonant deletion (31.4), liquid simplification (21.6), glottalization (15.7), tensing (5.9), typi- } \\
\text { cal simplification of consonant clusters between syllables (5.9) }\end{array}$ \\
\hline 9 & $4 ; 6$ & $\mathrm{~F}$ & 50.0 & 5.8 & 9.7 & $\begin{array}{l}\text { Backing to velars (45.9), liquid simplification (18.0), deaspiration (13.1), unroundess of vowel(4.9), } \\
\text { typical simplification of consonant clusters between syllables(4.9) }\end{array}$ \\
\hline 10 & $3 ; 11$ & $\mathrm{~F}$ & 50.0 & 5.8 & 10.3 & $\begin{array}{l}\text { Fronting of velars (40.8), stopping (32.7), nasalization-stopping of liquid (10.2), typical simplifica- } \\
\text { tion of consonant clusters between syllables (8.2), monophthongization (6.1) }\end{array}$ \\
\hline 11 & $4 ; 3$ & M & 57.3 & 5.6 & 9.7 & $\begin{array}{l}\text { Typical simplification of consonant clusters between syllables (27.3), affrication (22.7), liquid } \\
\text { simplification (20.5), denasalization (9.1), final consonant deletion (6.8) }\end{array}$ \\
\hline 12 & $5 ; 3$ & M & 57.3 & 5.9 & 10.2 & $\begin{array}{l}\text { Stopping (39.6), liquid simplification (22.9), typical simplification of consonant clusters between } \\
\text { syllables (14.6), monophthongization (8.3) }\end{array}$ \\
\hline
\end{tabular}

$\mathrm{PCC}=$ percent consonants correct; $\mathrm{PMLU}=$ phonological mean length of utterance; $\mathrm{PMLU}-\mathrm{W}=$ weighted phonological mean length of utterance.

values in parenthesis indicate the possible highest score of each measure.

balues in parenthesis indicate the percentage of each error pattern out of the child's entire error patterns.

Table 4. Three measurements and phonological error patterns of children who presented $70 \%-80 \%$ of PCC

\begin{tabular}{|c|c|c|c|c|c|c|}
\hline Case no. & $\begin{array}{c}\text { Age } \\
(y r ; m o)\end{array}$ & Gender & $\begin{array}{c}\text { PCC } \\
(100 \%)^{\mathrm{a}}\end{array}$ & $\begin{array}{l}\text { PMLU } \\
(7.3)^{a}\end{array}$ & $\begin{array}{l}\text { PMLU-W } \\
(12.1)^{\mathrm{a}}\end{array}$ & Main phonological error patterns ${ }^{b}$ \\
\hline 13 & $4 ; 6$ & M & 72.9 & 6.5 & 10.9 & $\begin{array}{l}\text { Fronting of velars (41.9), typical simplification of consonant clusters between syllables (22.6), } \\
\text { backing to velars (12.9), monophthongization (12.9) }\end{array}$ \\
\hline 14 & $5 ; 9$ & M & 72.9 & 6.5 & 11.0 & $\begin{array}{l}\text { Stopping (57.1), typical simplification of consonant clusters between syllables (14.3), liquid simplifi- } \\
\text { cation (14.3) }\end{array}$ \\
\hline 15 & $4 ; 11$ & $\mathrm{~F}$ & 76.0 & 6.6 & 11.1 & Labialization (21.7), labiodentalization (21.7), stopping (21.7), glottalization (17.4) \\
\hline 1 & $4 ; 0$ & $\mathrm{~F}$ & 76.0 & 6.6 & 11.3 & Stopping (75.0), liquid simplification (16.7) \\
\hline 17 & $5 ; 2$ & M & 80.2 & 6.7 & 11.3 & Stopping (73.7), final consonant deletion (15.8) \\
\hline 18 & $4 ; 8$ & M & 80.2 & 6.7 & 11.3 & Lateralization of affricates and fricatives (77.8) \\
\hline
\end{tabular}

$\mathrm{PCC}=$ percent consonants correct; $\mathrm{PMLU}=$ phonological mean length of utterance; $\mathrm{PMLU}-\mathrm{W}=$ weighted phonological mean length of utterance.

Values in parenthesis indicate the possible highest score of each measure.

balues in parenthesis indicate the percentage of each error pattern out of the child's entire error patterns.

Bold error patterns indicate those occurring within $50 \%$ of upper cumulative ratio. 
PMLU-W가 2점 이상 낮아졌다. 아동 4와 5는 공통적으로 종성 생 략이 빈번하였지만, 그밖에 빈번한 오류패턴이 아동 4 의 경우 초성 생략이었고 아동 5 의 경우 모음의 오류 및 자음의 활음화였다. 결 국 세 아동은 PCC는 동일하였지만, 음절생략, 자음생략, 음운대치 라는 주된 오류패턴의 특성 차이가 PMLU와 PMLU-W에 차별적 으로 반영되어, 아동 3, 4,5 의 순서로 PMLU와 PMLU-W 수치가 증 가하였다.

아동 6와 7도 PCC가 29.2\%로 동일하였으나, 아동 6은 초성 및 종성의 생략이 빈번했던 반면, 아동 7은 순치음으로의 왜곡이나 연 구개음의 전방화 대치가 빈번하여 아동 6의 PMLU 및 PMLU-W가 아동 7보다 낮았다. 이상의 결과는 PCC가 $10 \%-30 \%$ 로 심한(severe) 말소리장애를 보이는 아동이라도 주요 오류패턴은 음절생략, 자음생략, 모음대치, 자음대치, 자음왜곡으로 다양하므로, 자음의 정확성 여부만을 이분법적으로 계산하는 PCC보다음절구조의 정 확성과 모음의 정확성까지 반영하는 PMLU나 PMLU-W가 조음 문제를 보다 더 적절하게 정량화해 줌을 보여주었다.

Table 3은 PCC가 50\%-60\%인 말소리장애 아동의 분석결과를 제시하고 있다. 아동 $8,9,10$ 은 PCC가 모두 $50.0 \%$ 로 동일한 정도의 말소리장애 심각도를 보이지만, 세 아동의 주된 오류패턴은 각각 종성생략, 연구개음화, 연구개음의 전방화로 모두 달랐다. 생략오류 를 보인 아동 8 은 연구개음화나 연구개음의 전방화와 같은 대치오 류를 보인 다른 두 아동에 비해 상대적으로 낮은 PMLU와 PMLU$\mathrm{W}$ 를 보였다. 한편 아동 9 와 10은 PCC뿐만 아니라 PMLU도 5.8로 동일한 수치를 보였으나 PMLU-W에서는 차이가 났다. 아동 9의 주 된 오류패턴은 연구개음의 전방화로, 이 오류는 연구개 파열음과 비음이 치경파열음과 비음으로 대치되므로 조음위치에만 변화를 보였다. 그러나 아동 10 의 주된 오류패턴은 연구개음화로, 이 오류 에는 치경파열음과 비음이 연구개 파열음과 비음으로 대치되는 변 화와 치경마찰음과 치경유음과 경구개 파찰음이 연구개 파열음으 로 대치되는 변화가 모두 포함되는데, 마찰음과 유음과 파찰음의 변화는 조음위치뿐만 아니라 조음방법에도 변화를 가져온다. 이에 따라 아동 9 의 대치오류에는 대부분 2점의 추가점수가 부여되지 만, 아동 10 의 대치오류에는 1 점의 추가점수만 부여되는 경우가 많 았고, 그 결과로 PMLU는 동일해도 PMLU-W에는 차이가 났다.

아동 11,12 도 모두 $57.3 \%$ 의 동일한 PCC를 보였으나, 아동 11 은 아동 12에 비해 낮은 PMLU와 PMLU-W를 보였다. 두 아동의 오류 패턴을 살펴보면, 아동 11 은 생략오류가, 아동 12 는 대치오류가 상 대적으로 더 많았다. 또한 두 아동 모두 전형적 어중 단순화가 관찰 되었는데, 아동 11 은 탈비음화로 어중종성이 생략되었지만 아동 12 는 조음위치 역행동화로 어중 종성이 대치되었고, 이러한 특성
차이가 PMLU와 PMLU-W 수치에도 반영되었다. 이상의 결과는 PCC가 50\%-60\%에 해당하는 심각도가 중등도(moderate)인 말소 리장애 아동은 음절생략은 없지만, 종성생략과 함께 다양한 대치 오류가 나타나며, 조음방법, 조음위치, 발성유형이 모두 부정확한 대치에서부터 그 중 하나만 부정확한 대치까지 다양한 특징을 보 이므로, 대치음에 따라 추가점수를 달리하는 PMLU-W가 다른 두 측정치에 비해 아동의 말소리장애 특성을 보다 세밀하게 정량화한 다고 할 수 있었다.

Table 4 에는 PCC가 70\%-80\%인 6명의 말소리장애 아동의 분석 결과를 제시하였다. 이 6 명의 아동은 각각 동일한 PCC를 보이는 3 쌍으로 분류가 가능한데, 이들의 주된 오류패턴도 파열음화, 연구 개음의 전방화, 양순음화, 설측음화로 다양하였다. 그러나 각 쌍마 다 PMLU도 모두 동일하였고, PMLU-W도 .1-.2점 정도밖에 차이 가 나지 않았으며, 더욱이 주된 오류 패턴이 비발달적이라고 해서 더 낮은 점수를 나타내는 것도 아니었다. 따라서 PCC가 70\%-80\% 에 해당하는 심각도가 경도(mild)인 말소리장애 아동은 모두 음절 구조의 변화 없이 자음 자질 중 한가지만 달라지는 대치나 왜곡오 류를 보이므로, PMLU-W가 다른 두 측정치에 비해 아동의 말소리 장애 특성을 보다 세밀하게 정량화한다고 볼 수는 없었다.

\section{논의 및 결론}

본 연구는 PMLU-W라는 새로운 지표를 제안하고, 일반 아동과 말소리장애 아동의 말 자료 분석결과를 기존의 대표적인 말소리 측정치와 비교하면서 PMLU-W가 일반적인 조음음운발달과 말소 리장애를 민감하고 타당하게 반영하는지 살펴보고자 하였다. 먼저 PMLU-W가 일반아동의 말소리 습득 과정을 민감하게 반영하는 지 APAC 평가 맥락에서 PCC 및 PMLU와 비교하였다. PMLU-W 는 다른 두 측정치와 높은 상관관계를 보이면서 조음음운발달 과 정을 민감하게 보여주었다. 이러한 결과는 새롭게 제안한 PMLU$\mathrm{W}$ 가 이미 연구와 임상현장에서 타당도가 입증된 PCC 및 PMLU 와 마찬가지로 아동의 말소리 습득을 객관적이고 타당하게 평가할 수 있는 지표로 사용될 수 있음을 지지하는 것이다.

두 번째 연구에서는 새롭게 제안한 측정치가 말소리장애 아동의 특성을 차별적으로 나타내는지 살펴보고자 APAC 평가맥락에서 $\mathrm{PCC}$ 가 동일한 말소리장애 아동의 PMLU와 PMLU-W, 오류패턴 을 비교하였다. PCC가 $10 \%-30 \%$ 인 말소리장애 아동 중에는 PCC 가 동일해도 PMLU와 PMLU-W에 상이한 차이를 보이는 경우가 있었다. 이 그룹에는 대부분의 음절을 생략하는 아동, 대부분의 자 음을 생략 또는 성문음화하는 아동, 대부분의 자음을 대치 또는 
왜곡하는 아동이 모두 포함되어 있었으며, 이러한 오류패턴의 다양 성이 PCC에는 반영되지 못하지만 PMLU나 PMLU-W에 반영될 수 있었다. 그러므로 음절 및 자음생략과 같은 통단어 변동이 많은 심도의 말소리장애 아동은 PMLU나 PMLU-W를 이용해 말 문제 를 평가하는 것이 더 타당하고 유용할 수 있다.

본 연구에서 새롭게 제안한 PMLU-W가 기존의 PMLU와 차별 되는 점은 자음의 대치오류 중 조음방법, 조음위치, 발성유형 중 한 측면에서만 오류를 보인 대치와 여러 측면에서 오류를 보인 대치를 구분하여 추가점수를 부여한 점이다. 이러한 PMLU-W의 특징적 인 점수체계는 PCC가 $50 \%-60 \%$ 인 말소리장애 아동의 분석결과에 잘 나타났다. 이 그룹에는 대치오류가 빈번한 아동들이 많았다. 그 중에서 조음위치만 대치되는 연구개음의 전방화 아동과 조음위치 뿐만 아니라 조음방법도 대치되는 연구개음화 아동은 동일한 수치 의 PCC와 PMLU를 보이더라도 PMLU-W에는 차이가 났다. 또한 이 그룹 아동들은 모두 어중 단순화를 보였는데, 탈비음화의 결과 로 어중자음이 생략되는 아동과 조음위치 역행동화의 결과로 어중 자음이 대치되는 두 아동도 PCC는 동일했지만, PMLU나 PMLU$\mathrm{W}$ 에는 이러한 차이가 반영되었다. 따라서 음소변화변동이 많은 중 등도의 말소리장애 아동들도 PMLU-W를 통해서 자음의 조음방 법, 조음위치, 발성유형의 여러 측면에서 오류를 보이는 대치와 한 측면에서만 오류를 보이는 대치를 차별적으로 세밀하게 평가할 수 있을 것이다.

또한 PMLU-W는 자음의 정확성만을 고려하여 추가점수를 부 여하는 PMLU와는 달리 모음의 정확성에도 추가점수를 부여하였 다. 2 세 이후의 일반아동은 모음오류가 거의 없지만, 표현언어지체 나 말소리장애 아동 중에는 고모음 산출 시 혀위치 조절이 어려워 전설모음화하거나, 중모음 산출 시 턱높이 조절이 어려워서 저모음 화 또는 고모음화하는 경우가 종종 있었다. 실제로 심도의 말소리 장애 아동 중에는 높은 비율의 모음오류를 보이는 사례가 있었고, 이 사례를 PCC나 PMLU로 분석한다면 아동의 중요한 음운특성 을 간과하게 된다. 따라서 모음오류가 많은 말소리장애 아동이나 아동기 말 실행증 아동을 평가할 때는 PMLU보다 PMLU-W가 더 유용할 수 있겠다.

그러나 PCC가 $70 \%$ 이상인 경도의 말소리장애 아동은 PCC, PMLU, PMLU-W에 큰 차이가 없었다. 일반아동 연구에서도 비록 PMLU-W가 PCC 및 PMLU와 마찬가지로 아동의 말소리 습득 과 정을 잘 나타내 주었지만, PCC나 PMLU에 비해 연령별 차이를 더 두드러지게 보여주지 못했는데, 이는 연구대상인 일반아동의 PCC 가 $70 \%$ 이상이었던 사실과 연관된 것으로 판단된다.

모음의 정확성도 고려하고 자음의 정확성도 대치 양상을 세분하
여 차등적으로 점수화한 가중평균음운길이는 일반아동의 말소리 발달 및 말소리장애 아동의 말소리 특징을 잘 나타내주었다. 특히 말소리장애 아동의 다양한 생략 및 대치오류를 차별적으로 정량 화할 수 있었다. 이러한 PMLU-W의 차별적인 점수체계는 말소리 장애의 평가뿐만 아니라 치료 진전 정도를 정량화하는 데에도 효 과적일 것으로 판단된다. 음절구조 및 말소리 목록이 극히 제한되 고 모음에까지 오류를 보였던 아동이 치료를 통해 모음이 정확해 지고, 음절구조가 확장되며, 자음의 조음방법, 조음위치, 발성유형 자질이 점진적으로 정확해지는 과정을 반영하기 위해서는 PCC나 PMLU보다 PMLU-W가 좀 더 민감하고 타당한 지표가 될 수 있을 것이다. 추후 지속적인 연구를 통해 말소리장애 아동의 평가와 치 료에 PMLU-W의 효율성을 구체적으로 입증해 나가는 것이 필요 하겠다. 마지막으로 PMLU-W의 점수체계를 좀 더 고민해볼 필요 가 있다. 자질의 유사성에 근거한 점수체계로는 발달적 오류패턴과 비발달적 오류패턴을 구분하는 데 한계가 있었다. 예를 들어 연구 개음을 치경음으로 대치하는 발달적 패턴과 파열음을 비음으로 대 치하는 비발달적 패턴에 동일한 점수가 부여되었고, 치간음으로 왜 곡하는 발달적 패턴과 설측음으로 왜곡하는 비발달적 패턴에도 동 일한 점수가 부여된 점은 앞으로 이 점수체계가 좀 더 정교하게 수 정·보완되어야 할 필요성을 시사하였다.

\section{REFERENCES}

Ahn, M., Kim, U., \& Kim, T. (2004). The acquisition process of vowel system in Korean. Korean Journal of Cognitive Science, 15, 1-11.

Bernthal, J., Bankson, N., \& Flipsen, P. (2013). Articulation and phonological disorders: speech sound disorders in children (7th ed.). Boston, MA: Pearson.

Chapman, K. L., Hardin-Jones, M., \& Halter, K. A. (2003). The relationship between early speech and later speech and language performance for children with cleft lip and palate. Clinical Linguistics \& Phonetics, 17, 173-197.

Davis, B. L., Jakielski, K. J., \& Marquardt, T. P. (1998). Developmental apraxia of speech: determiners of differential diagnosis. Clinical Linguistics \& Phonetics, 12, 25-45.

Dodd, B., \& Bradford, A. (2000). A comparison of three therapy methods for children with different types of developmental phonological disorder. International Journal of Language \& Communication Disorders, 35, 189-209.

Ha, S., \& Hwang, J. (2013). Speech measures from phonological analyses of spontaneous conversations in children between 18-47 months of age. Communication Sciences \& Disorders, 18, 425-434.

Ha, S., Seol, A., So, J., \& Pae, S. (2016). Speech and language development 
patterns of Korean two-year-old children from analysis of spontaneous utterances. Communication Sciences \& Disorders, 21, 47-59.

Ingram, D. (2002). The measurement of whole-word productions. Journal of Child Language, 29, 713-733.

Ingram, D., \& Ingram, K. D. (2001). A whole-word approach to phonological analysis and intervention. Language, Speech, and Hearing Services in Schools, 32, 271-283.

Kim, M. J. (2012). Treatment of children with phonological cases accompanied by expressive language delay. The Korean Academy of Speech-Language Pathology and Audiology \& The Korean Association of Speech-Language Pathologists Joint Workshop Casebook, 69-87.

Kim, M. J. (2015). Denasalization error pattern for typically developing and SSD children. Phonetics and Speech Sciences, 7, 3-8.

Kim, M. J., \& Lee, S. E. (2010). Phonological error patterns: clinical aspects on coronal feature. Phonetics and Speech Sciences, 2, 239-244.

Kim, M. J., Pae, S., \& Park, C. I. (2007). Assessment of Phonology and Articulation for Children (APAC). Incheon: Human Brain Research \& Consulting Co.

Kim, Y. T., Jang, H. S., Yim, S. S., \& Baek, H. J. (1995). Picture Vocabuarly Test. Seoul: Seoul Community Rehabilitation Center.

Lowe, R. J. (1994). Phonology: assessment and intervention application in speech pathology. Baltimore, MD: Williams \& Wilkins.

Pi, M., \& Ha, S. (2018). Relationship between phonological, lexical, and grammatical skills in 18- to 30-month-old Korean children. Communication Sciences and Disorders, 23, 1-10.
Pollock, K. E. (1991). The identification of vowel errors using traditional articulation or phonological process test stimuli. Language, Speech, and Hearing Services in Schools, 22, 39-50.

Preston, J. L., Ramsdell, H. L., Oller, D. K., Edwards, M. L., \& Tobin, S. J. (2011). Developing a weighted measure of speech sound accuracy. Journal of Speech, Language, and Hearing Research, 54, 1-18.

Seok, D. I. (2004). A whole-word approach to phonological analysis with phonological disorders. Journal of Special Education: Theory and Practice, 5, 87-102.

Shin, H. J., \& Lee, E. J. (2015). Phonological characteristics of late-talkers through phonological whole-word analysis. Communication Sciences \& Disorders, 20, 157-165.

Shriberg, L. D., \& Kwiatkowski, J. (1982). Phonological disorders III: a procedure for assessing severity of involvement. Journal of Speech and Hearing Disorders, 47, 256-270.

Shriberg, L. D., Austin, D., Lewis, B. A., McSweeny, J. L., \& Wilson, D. L. (1997). The percentage of consonants correct (PCC) metric: extensions and reliability data. Journal of Speech, Language, and Hearing Research, 40, 708722.

Woo, H., \& Kim, S. (2013). Coda sounds acquisition at word medial position in three and four year old children's spontaneous speech. Phonetics and Speech Sciences, 5, 73-81.

Yoon, M. S., Kim, J. M., \& Kim, S. J. (2013). Phonological whole-word measures of spontaneous speech in children two to four years of age. Journal of Speech-Language \& Hearing Disorders, 22, 69-85. 
Appendix 1. 음운패턴의 정의

\begin{tabular}{|c|c|c|c|c|}
\hline \multicolumn{4}{|l|}{ 음운패턴 } & 정의 \\
\hline \multirow[t]{8}{*}{ 통 단어 음운패턴 } & \multicolumn{3}{|l|}{ 음절 생략 } & 음절을 생략한다. \\
\hline & \multicolumn{3}{|l|}{ 초성 생략1) } & 어두초성 또는/그리고 어중초성을 생략한다. \\
\hline & \multicolumn{3}{|l|}{ 종성 생략ㄹ) } & 어중종성 또는/그리고 어말종성을 생략한다. \\
\hline & \multicolumn{3}{|c|}{ 음절 및 음소 첨가3) } & 음절을 첨가하거나 음소를 첨가한다. \\
\hline & \multicolumn{3}{|l|}{ 음절 반복4) } & 음절을 반복한다. \\
\hline & \multicolumn{3}{|l|}{ 자음 조화 ${ }^{4)}$} & 자음 또는 자음의 자질 일부를 반복한다. \\
\hline & \multicolumn{3}{|c|}{ 전형적 어중 단순화5) } & 어중종성이 생략되거나, 어중초성에 의해 역행동화된다. \\
\hline & \multicolumn{3}{|c|}{ 비전형적 어중 단순화 } & 자음연쇄에서 어중초성이 어중종성에 의해 순행동화된다. \\
\hline \multirow[t]{20}{*}{ 음소 변화 음운 패턴 } & \multirow[t]{7}{*}{ 조음 위치 변화6) } & \multicolumn{2}{|l|}{ 연구개음의 전방확) } & 연구개음을 치경음이나 경구개음으로 대치한다. \\
\hline & & \multicolumn{2}{|l|}{ 양순음화 } & 성문음, 연구개음, 경구개음, 또는 치경음을 양순음으로 대치한다. \\
\hline & & \multicolumn{2}{|l|}{ 치경음-경구개음확) } & 양순음을 치경음 또는 경구개음으로 대치한다. \\
\hline & & \multicolumn{2}{|l|}{ 연구개음화 } & 양순음, 치경음, 경구개음, 또는 성문음을 연구개음으로 대치한다. \\
\hline & & \multicolumn{2}{|l|}{ 성문음화 } & 양순음, 치경음, 경구개음, 또는 연구개음을 성문음으로 대치한다. \\
\hline & & \multirow[t]{2}{*}{ 왜곡 예 } & 앞으로 & 순치음화, 치간음화, 치음화8) \\
\hline & & & 뒤로 & 권설음화, 구개음화, 연구개음화 \\
\hline & \multirow[t]{8}{*}{ 조음 방법 변화 } & \multicolumn{2}{|l|}{ 파열음화9) } & 파찰음 또는 마찰음을 파열음으로 대치한다. \\
\hline & & \multicolumn{2}{|l|}{ 파찰음화 } & 마찰음을 파찰음으로 대치한다. \\
\hline & & \multicolumn{2}{|l|}{ 마찰음화 } & 파열음 또는 파찰음을 마찰음으로 대치한다. \\
\hline & & \multicolumn{2}{|l|}{ 탈비음화9) } & 비음을 장애음(파열음, 파찰음, 마찰음)으로 대치한다. \\
\hline & & \multicolumn{2}{|l|}{ 비음화 } & 장애음(파열음, 파찰음, 마찰음)을 비음으로 대치한다. \\
\hline & & \multicolumn{2}{|l|}{ 유음의 단순화 ${ }^{10)}$} & 유음을 생략하거나 활음으로 대치한다. \\
\hline & & \multicolumn{2}{|l|}{ 유음의 비음-파열음화 ${ }^{10)}$} & 유음을 비음 또는 파열음으로 대치한다. \\
\hline & & \multicolumn{2}{|l|}{ 왜곡 예 } & 설측음화, 겹자음화 ${ }^{11)}$, 약화 \\
\hline & \multirow[t]{5}{*}{ 발성 유형 변화 } & \multicolumn{2}{|l|}{ 긴장음화 } & 평음을 경음으로 대치한다. \\
\hline & & \multicolumn{2}{|l|}{ 이완음화 } & 경음 또는 격음을 평음으로 대치한다. \\
\hline & & \multicolumn{2}{|l|}{ 탈기식음화 } & 격음을 경음으로 대치하거나 /흐를 탈락시킨다. \\
\hline & & \multicolumn{2}{|l|}{ 기식음화 ${ }^{12)}$} & 평음 또는 경음을 격음으로 대치한다. \\
\hline & & 왜곡 예 & & 유성음화 \\
\hline
\end{tabular}

1)/히만 생략했거나 /리만 생략했다면, 이는 각각 탈기식음화와 유음의 단순화로 분석한다.

2)/ㄹ/만 생략했거나 어중종성만 생략했다면, 이는 각각 유음의 단순화와 전형적 어중 단순화로 분석한다.

3)어중초성이 길어져서 어중종성에 동일한 자음이 첨가되는 현상은 겹자음화 왜곡으로 분석한다.

4)해당 단어에서만 관찰되는 현상으로, 음소변화 변동의 결과가 아님이 확인되어야 하며, 음절 반복이나 자음 조화로 확인되면 음소변화 변동을 적용시키지 않는다.

${ }^{5)}$ 어중종성에서만 관찰되는 현상으로, 어중종성과 어말종성에서 모두 생략되거나 동일하게 대치되면, 각각 종성생략과 음소변화 변동으로 분석한다. 또한 모음 사이에 서 어중초성이 생략되는 현상은 초성생략으로 분석한다. 이 변동에는 탈비음화의 결과로 종성이 생략되고 초성이 경음화되는 현상도 포함될 수 있다.

6)조음위치 변동의 결과로 발생하는 조음방법 변동은 따로 분석하지 않는다. 예를 들어, / ᄀ/를 / ㅈ/로 대치한 것을 파찰음화로 분석하거나, / 지를 / ᄀ/로 대치한 것을 파 열음화로 분석하지 않는다.

7)발달적 음운패턴인 연구개음의 전방화와 비발달적 음운패턴인 치경음-경구개음화는 구분하여 분석한다.

8)경구개 파찰음 및 마찰음의 조음위치가 치경 파찰음 및 마찰음으로 왜곡되는 현상을 의미한다.

9)발달적 음운패턴인 파열음화와 비발달적 음운패턴인 탈비음화는 구분하여 분석한다.

${ }^{10)}$ 유음의 생략이 초성과 종성 모두에서 관찰되면 이는 초성 또는 종성생략이 아니라 유음단순화로 분석한다. 유음이 초성 및 어말종성에서는 정조음되지만 어중종성에 서만 생략되면 어중 단순화로 분석한다.

${ }^{11)}$ 어중초성이 길어져서 어중종성에 동일한 자음이 첨가되는 현상으로, 유음에서 탄설음이 설측음으로 산출되는 현상이 이에 포함된다.

12)장애음 중 기식음이 없는 마찰음 /ᄉ, 씨가 / $E$,치로 대치된 것은 기식음화의 범주에 포함시키지 않는다. 


\section{국문초록}

\section{가중평균음운길이의 개발과 타당도 검증}

김민정 $\cdot$ 하승희 ${ }^{2}$

'도곡연세 말-언어연구소, ${ }^{2}$ 한림대학교 언어청각학부, 한림청각언어연구소

배경 및 목적: 말소리 산출 능력을 정확하고 민감하게 반영할 수 있는 객관적 지표를 개발하고 타당성을 살펴보는 것은 중요하다. 본 연 구에서는 가중평균음운길이라는 새로운 측정치를 제안하였으며, 일반아동과 말소리장애 아동의 말 자료를 토대로 자음정확도 및 평 균음운길이와 비교하면서 가중평균음운길이의 타당도를 살펴보고자 하였다. 방법: 음절구조와 모음정확도, 자음의 자질정확도 정보 를 포함하는 측정치와 점수체계를 개발하였다. 그리고 만 2 세 후반부터 6 세 전반의 일반아동 220 명과 말소리장애 아동 18 명의 아동용 발음평가 자료에서 자음정확도, 평균음운길이, 가중평균음운길이를 구하였다. 일반아동은 6개월 단위로 월령집단을 나누어 조음음 운능력의 발달을 살펴보았다. 말소리장애 아동은 자음정확도를 토대로 심각도별 하위 유형을 나눈 후 자음정확도는 동일하지만 주요 오류패턴이 상이한 말소리장애 아동끼리 평균음운길이 및 가중평균음운길이를 살펴보았다. 결과: 가중평균음운길이는 다른 두 측정 치와 높은 상관관계를 보이면서 일반아동의 조음음운발달을 민감하게 보여주었다. 자음정확도가 $20 \%-30 \%$ 이거나 $50 \%-60 \%$ 인 말소리 장애 아동의 가중평균음운길이는 실증적으로 자음정확도 및 평균음운길이와는 구별되게 음절 및 자음의 생략, 조음의 오류, 조음위 치 및 조음방법이 모두 변하는 대치오류에 대한 정보를 반영하였다. 논의 및 결론: 모음의 정확성도 고려하고 자음의 대치패턴에 따라 점수를 세분화한 가중평균음운길이는 조음음운발달을 민감하게 반영하고, 말소리장애 아동의 조음오류 유형과 특성을 정량화하는 데 유용하게 사용될 수 있다.

핵심어: 자음정확도, 평균음운길이, 가중평균음운길이, 일반아동, 말소리장애

이 연구는 한림대학교 교비 학술연구과제(HRF-201807-008)에 의해 수행되었음.

\section{참고문헌}

김민정(2012). 표현언어지체를 동반한 아동의 음운치료사례. 한국언어청각임상학회 한국언어재활사협회 공동연수회 자료집, 69-87.

김민정(2015). 일발 및 말소리장애 아동의 탈비음화 오류패턴. 말소리와 음성과학, 7,3-8.

김민정, 배소영, 박창일(2007). 아동용 발음평가(APAC). 인천: 휴브알앤씨.

김민정, 이성은(2010). 음운 오류패턴: 설정성 자질의 임상적 고찰. 말소리와음성과학, 2, 239-244.

김영태, 장혜성, 임선숙, 백현정(1994). 그림어휘력 검사. 서울: 서울장애인종합복지관.

석동일(2004). 단어단위 접근법에 의한 조음 음운장애아동의 음운분석. 특수교육저널: 이론과 실천, 5, 87-102.

신화정, 이은주(2015). 단어단위음운분석에 의한 말 늦은 아동의 음운 특성. 언어청각장애연구, 20, 157-165

안미리, 김응모, 김태경(2004). 한국어 모음 체계 습득 과정. 인지과학, 15, 1-11.

우혜경, 김수진(2013). 자발화에 나타난 3-4세 아동의 어중종성 습득. 말소리와 음성과학, 5, 73-81.

윤미선, 김정미, 김수진(2013). 자발화 문맥에서의 단어단위음운평가. 언어치료연구, 22, 69-85.

피민경, 하승희 (2018). 18-30개월 아동의 자발화에 나타난음운, 어휘, 문법 능력의 관계. 언어청각장애연구, 23, 1-10.

하승희, 설아영, 소정민, 배소영(2016). 자발화 분석을 통한 만 2 세 한국아동의 말-언어발달 특성. 언어청각장애연구, 21, 47-59.

하승희, 황진경(2013). 18-47개월 아동의 자발화 분석에 기초한 말소리 측정치에 관한 연구. 언어청각장애연구, 18, 425-434. 